\title{
Negative effects of massive emigration originating from the Republic of Moldova
}

\author{
Doina Guzun ${ }^{1}$, Dorin Dusciac ${ }^{2}$, Ala Mindicanu ${ }^{3}$, Sandra Ayad ${ }^{4}$ Frédéric Boisard $^{5}$ \\ ${ }^{1}$ University Paris Diderot-Paris 7, France. \\ ${ }^{2}$ President of the Association for the Integration of Migrants (AIM), Paris, France, \\ Deputy Minister - Ministry of Environment of the Republic of Moldova (2014 - 2015). \\ ${ }^{3}$ President of the Moldovan Community of Québec, Member of the Parliament of the \\ Republic of Moldova (1994 - 2001). \\ ${ }^{4}$ Head of the Center for International Research and Documentation of Sexual \\ Exploitation, Scelles Foundation, Paris, France. \\ ${ }^{5}$ Community manager, Center for International Research and Documentation of Sexual \\ Exploitation, Scelles Foundation, Paris, France. \\ e-mail: doina.guzun@gmail.com
}

Acknowledgement: This contribution is part of the 4th Global Report Prostitution. Exploitation, Prosecution, Repression, edited by the Scelles Foundation (Paris, France), under the Direction of Yves Charpenel, Deputy General Prosecutor of the Supreme Court of France, President of the Scelles Foundation (ECONOMICA ED., 49, rue Héricart, 75015 Paris, France), 2016. The book will be available for free downloading on: www.fondationscelles.org

\section{Introduction}

According to the Prosecutor General of the Republic of Moldova, 164 crimes of human trafficking were reported during the first six month of 2015 (compared to 169 in the same period of 2014) along with 38 cases of procuring. The Moldovan Mission to the International Organization for Migration (IOM) estimated that $70 \%$ of procurers in Moldova are women (IOM, 2013). This can be explained by the fact that most of those who have been accused are already involved in prostitution abroad. For example, a woman between the ages of 20 and 23 who was first a victim of trafficking or a prostituted person, may subsequently become a procurer by the age of 26. The same study provided information on prostituted female witnesses, but there are no statistics on the number of Moldovan nationals practicing prostitution within or outside of the country (Bulletin of the Supreme Court of Justice of the Republic of Moldova, 2005). No other study or source to date provides comprehensive data on prostitution in Moldova. The question is whether this lack of data is due to a low rate of prostitution or Moldovan authorities ignoring many cases.

More than $50 \%$ of young Moldovans surveyed wish to go abroad, giving rising unemployment and miserable wages as their main reasons. Women constitute $68 \%$ of the unemployed and are exposed to longer periods of unemployment than men. Although they are educated to the same level as men, they make up three-quarters of the unskilled labor force and are paid $70-80 \%$ of men's salaries, while doing a double work-load since their working day continues at home. That is why they wish to go abroad and find jobs that would pay more than the average wage in Moldova, even though they know a lot about possible risks.

Moldovan women working abroad are mostly active in the caring professions or services (nursing, hospital orderlies, agriculture) and are paid a half or a quarter of the pay rate for locals. One of the most painful features of migration is women's involvement in prostitution and trafficking. According to some national statistics, more than 100,000 Moldovan women were trafficked in 1995- 
2002 to countries such as Turkey, Israel, Spain, Portugal, Greece, Germany, Italy, Cyprus, etc. over the last ten years.

Official statistics show a massive number of Moldovan women in Kosovo during the conflict period, accounting for $61 \%$ of all the trafficked persons there. Most of them were brought by force and many sold to various owners, without recourse to any legal assistance or any psychological or material support.

However, Moldova remains classified as Tier 2 in the 2014 U.S. Department of State Report on Trafficking in Persons, signifying that the country is still facing serious problems regarding the sex trafficking of women and children. Representatives of the Moldovan authorities and civil society define prostitution as a "sin", therefore prostitutes are presented as "women without morals." This belief takes root in the ideals set by the Church, the government and the society. This way of thinking is actually the main opponent to legalizing prostitution.

\section{Prostitution and Easy Money}

According to Moldovan psychologists, girls who are involved in the sex trafficking industry have incurred trauma related to sexual abuse. They argue that $40 \%$ of these young women were once victims of incest or rape at an early age (Ziarul de Garda, February $7^{\text {th }}, 2013$ ). These traumas induce serious personality disorders, leading women to agree to have sex for "easy money".

However, over the last few decades, the Moldovan society has evolved enough in the field of prostitution to see its practices diverse considerably. The economic emergence of those practices occurred rapidly in an uncontrolled environment, making easy money the main driving force of economic, cultural and social activities. With this in mind, it's quite apparent to state that the popularity of prostitution increased overtime. Making money quickly and "effortlessly", even if it involves illegal and immoral activities, has become a normal way of life for a significant number of young Moldovans, not only those from vulnerable families and the margins of society. This attitude of abandoning traditional values in exchange for a life of quickly acquired comfort has generated a new phenomenon: the practice of prostitution in public locations. "Library girls" began to appear in the Moldovan press circa 2015 and immediately attracted the public's attention both locally and beyond the Moldovan borders (Realitatea, January $7^{\text {th }}, 2015$ ). For several years, an alarming number of libraries have been hosting the prostitution of young girls via video conference. This behavior cannot only be explained by economic reasons. In most cases, these girls do not come from very poor families who practice this activity to support themselves. Most of them are actually studying or have another job, but wish to ensure an above-average lifestyle. This shows a clear mutation in the collective mentality of the Moldovan society. Any means are considered acceptable to achieve financial success, resulting from traditional values of work and morality giving way to material values.

In a similar context, there are many cases of Moldovan women and girls looking for rich husbands abroad to get a better life. Sometimes voluntarily and consciously, these girls choose to practice sexual services abroad where there are better financial conditions (Jail Crunch, 2014). A new form of prostitution known as "luxury prostitution" or "modeling prostitution" has become a successful industry, run by modeling agencies funded and managed by Moldovan oligarchs. A well-known example of this is the director of Fashion TV Moldova, Corneliu Vidrascu, who was accused of human trafficking and procuring in January 2015. Vidrascu worked for almost five years at the Ministry of the Interior, within the General Directorate for the Fight against Organized Crime and acted as one of the leaders in the Center against Trafficking in Human Beings (Promotime, January $3^{\text {rd }}, 2015$ ).

Newspapers advertisements play particular a role in attracting clients, with hidden announcements for sexual services or connections with Moldovan or foreign procurers. A study done by the International Center "La Strada" demonstrated that the most words used for attracting customers or future victims of sexual exploitation are either related to job search abroad ("assistance in preparing jobs," "visas for abroad," "employment contracts abroad") or under cover matrimonial advertisements ("mothers who want a good future for their daughters, contact us, we are in contact with wealthy husbands abroad"). To attract clients, women providing sexual services usually post their ads in the "erotic massage services" section. Erotic massage is not illegal in 
Moldova, which encourages a number of "providers" to conceal their activity in this way, regardless of where the encounters occur (massage salons, night clubs, personal residences...) (ProTV Moldova, July $\left.8^{\text {th }}, 2015\right)$. The recruitment of girls is also done through coded language, with advertisements for "girl dancers", "erotic masseuses" or through other online job offers (MoldovaNews, May $8^{\text {th }}, 2015$ ).

\section{New Environment - New Challenges}

Since the accession of the pro-European government in 2009, the Republic of Moldova has made significant progress in its rapprochement to the European Union. In 2009, Moldova also joined the Eastern Partnership, measure of the EU neighborhood policy to sign an Association Agreements between the EU and each of the six former Soviet republics. By demonstrating its insight and consistency, the Republic of Moldova was able to obtain a free movement regime within the EU so there is no visa required for travel within the EU for up to 90 days every six months. However, Moldovan citizens are not allowed to work in EU member countries without a visa. The visa-free regime came into force on April $28^{\text {th }}$, 2014, making Moldova the first country in the Eastern Partnership to benefit from this. After four years of intense negotiations, the Association Agreement (including an economic and political component) between Moldova and the EU was ratified by the Moldovan parliament in July 2014. Despite fears expressed by some associations and political parties opposing the pro-European government, the cancellation of visas did not cause a visible effect of any mass exodus of the population. Migration dynamics remain unchanged, and emigration figures have remained stable since 2014. As for forced emigration for sexual exploitation in other EU countries, the situation is still unclear. It is evident that the liberalization of movement to the European Union has facilitated access to the European space to those were not eligible for visas before. This is particularly true for vulnerable unemployed young people living in rural areas - the target population for procurers. Meanwhile, in May 2015, the Moldovan authorities declared that trafficking decreased following the implementation of the visa-free regime (Moldpres, May $\left.11^{\text {th }}, 2015\right)$.
The scale of living in the Republic of Moldova remains one of the lowest and official data regarding the rate of unemployment does not reflect the true state of matters almost at all. Data regarding massive emigration of labor force from the Republic of Moldova to the West varies between 600 thousand and one million citizens. Women constitute more than 60 per cent of this number. This avalanche of illegal migrants (who were never registered by anyone) was mostly employed in the service's sector: nursing, constructions, seasonal agricultural works, tourism, entertainment, etc. Those employees are paid poorly and aren't protected by the legislation of the host countries.

There are currently no quantitative studies establishing a causal link between the visa liberalization and the flow of trafficking victims from Moldova to the EU. Though one must still consider two aspects: visa liberalization facilitates the departure of victims of trafficking, but it also decreases the number of potential trafficking victims wanting to join family members or work in an EU country. The quantitative value of this effect has yet to be evaluated. In 2013, before the introduction of the visa-free regime, a number of information and communication actions were undertaken by the Moldovan authorities on issues related to the prevention and fight against human trafficking (Council of Europe, June 12 ${ }^{\text {th }}, 2014$ ). The new context allows the Moldovan border police to be more effective in identifying and investigating transnational criminal networks.

\section{Civil Society: a Mobilization against Prostitution and Human Trafficking}

The issue of human trafficking has become increasingly present in the Moldovan society. Recently, topics related to sexual exploitation have appeared more than ever in political discourse. Two legislative initiatives reflect this new recognition: a 2012 bill aimed at criminalizing clients of prostitution, and a 2013 bill on chemical castration of those convicted of pedophilia. However, these two initiatives were not widely discussed in society. Parliamentary debates have been marked by a conflict between MPs from different political parties. The bill on the criminalization of clients has not been approved by the majority of parliamentary representatives (Parlamentul Republicii Moldova, June $5^{\text {th }}, 2012$ ), 
and the bill on the castration of pedophiles was initially adopted, but eventually rejected after a few months by the Constitutional Court (TRM Moldova, July $\left.8^{\text {th }}, 2013\right)$.

Even though the subject of prostitution has been present in the speeches and in the programs of Moldovan politicians, this phenomenon remains largely ignored by the upper-political class. Nonetheless, one important manifestation of civil society against human trafficking exists. More and more books and plays dealing with the subject of sexual exploitation have emerged in recent years. This new literature is meant to reflect reality and is largely based on real cases and people. Authors met with victims, listened to their stories and transcribed them in a documentary and poetic fashion to alert the public and authorities on the issues of sexual exploitation. One of the newest and most popular books on prostitution and sexual exploitation is Bessarabian Nights (2014, Ed. Aurochs, in English) written by Stela Brinzeanu, a Moldovan writer who immigrated to the United Kingdom. It demonstrates to its readers that sexual exploitation is a reality of migration from east to west that has a significant social, psychological, and emotional impact.

Today, civil society and non-governmental organizations in Moldova conduct various activities for the prevention of human trafficking and the protection of victims. With the help of international and non-governmental organizations (the Moldovan Mission of the International Organization for Migration, the International Center "La Strada," the OSCE Office in Moldova, "Médecins du Monde," and the Switzerland Fund "Terre des Hommes"), several national and international seminars have been organized for professionals in the field (Ministerul Muncii, Protectiei Sociale si Familie, April 22 $\left.2^{\text {nd }}, 2015\right)$. This training is complemented by the distribution of practical guides and methodical and educational materials.

In general, the cooperative relationship between the state and civil society is satisfactory. Yet, this relationship cannot be called a "total harmonization." The 2014 U.S. Department of State Report on Trafficking in Persons and the report from the Group of Experts on Action against Trafficking in Human Beings (GRETA) of the Council of Europe formulated recommendations on this subject. According to these reports, the authorities in Moldova must take greater actions to encourage the participation of NGOs and public institutions in the fight against trafficking. NGOs active in the field should be allowed to participate in the decision making. It is also necessary that they support research in this field and adopt practical measures to implement effective cooperation and communication between the police and NGOs at the local level, particularly in the fight against prostitution.

\section{A Diligent Government and a Corrupt Legal System}

The fight against prostitution and sexual exploitation in Moldova began in the 1990s, when there was a lack of relevant legislation, an institutional mechanism with financial and organizational resources. Since then, the Moldovan government has made efforts in certain aspects of human trafficking, but it has also been negligent of others.

According to the Moldovan Bureau of Statistics, the rate of unemployment in 1998 for women was $17.8 \%$, compared to a mere $10.2 \%$ for men. Knowing that in 1994 that number was only $8.9 \%$ for women, it's important to realize that there has been a tremendous increase in women's unemployment. Data from 2004 shows that this number diminished to an acceptable $12 \%$. Nowadays, because massive emigration (more than 600.000 people) and trafficking are not considered to be consequences of unemployment, it is practically impossible to find representative statistics about unemployment in Moldova.

In 2013, the Inspector General of the Police (Inspectoratul General de Politie) was established as part of the institutional reform of the Ministry of Internal Affairs and within it, a Center against Trafficking in Human Beings was created. This unit has a multidisciplinary structure, composed of police officers, law enforcement officers, and professionals from the National Anti-Corruption Center, the Service of Intelligence, and the Customs Service and Border Police. In September 2013, the Permanent Secretariat of the National Committee to Prevent and Combat Human Trafficking, a government agency responsible for the coordination of anti-trafficking policy, developed a National Plan including 120 activities for the years to come (2014-2016). One of the most relevant activities is the arrangement of an annual 
national campaign for a "Week against Human Trafficking", which was created in 2012. This awareness campaign consists of a wide range of anti-trafficking actions, including: public courses, round tables, information and awareness videos, film screenings, photography exhibitions, television programs, and more. At the same time, the Permanent Secretariat monitors these activities organized by the territorial commissions and includes this data in a National Report. This data is usually included in the annual U.S. Department of State Report on Trafficking in Persons where the efforts of these commissions of coordination of actions against human trafficking at the local level are appreciated. A communication strategy was developed by the Permanent Secretariat and put into practice with the specialized website (www.antitrafic.gov.md). According to the GRETA report for 2014 and 2015, Moldova has made considerable progress in information, in education, and in awareness of human trafficking (GRETA, March $\left.4^{\text {th }}, 2015\right)$. During the reference period, more than 1,100 events and 2,100 extracurricular activities focusing on the prevention and fight against human trafficking took place in schools in collaboration with the Ministry of Education. It is still necessary to continue to promote gender equality, the fight against domestic violence, and the de-stigmatization of trafficking victims. According to these same reports, in 2014, 4,229 specialists (judges, prosecutors, psychologists, teachers...) were trained. The most important aspect of this training is the identification of victims, particularly during investigations and judicial proceedings. The Moldovan government has made some improvements in this area, but there is still a lack of resources, not mentioning the deficiency of legal, psychological, and financial services for the victims. So far, there is no compensation system available for all victims. The National Report on the prevention and fight against trafficking human beings for 2014 identified 264 victims of which 116 were trafficked for sexual exploitation (National Committee for Combating Trafficking in Human Beings, Permanent Secretariat, 2015). Nevertheless, the government is investing more resources in 38 Health Centers (Centre de Sanatate Prietenesti Tineretului) located in all regions of Moldova. These centers were created in 2013 by the Ministry of Health, in collaboration with the
United Nations and are free for those up to the age of 24. There are currently no statistics on the number of young women who have benefitted from these services. Considering the fact that trafficking can be explained by the socio-economic situation of a population, from 2012 to 2014, the Ministry of the Economy developed a series of economic programs through the Organization for Small and Medium Enterprises to prevent trafficking via small and medium investments.

A series of measures to strengthen the fight against prostitution have been included in several strategic documents adopted by the government in the framework of justice reforms (Justice Reform Strategy for 2011-2016, the National Strategy for the Prevention of Organized Crime for 2011-2016, and the Action Plan on Human Rights). Withal, the Moldovan government's efforts have been very minimal from a legal point of view. There are a number of ambiguities in the definitions of trafficking and prostitution in Moldovan legislation. For example, Article 89 of the Contraventions of the Republic of Moldova details the penalties for practicing prostitution (Parlamentul, Republica Moldova, January $16^{\text {th }}$, 2009), but the Moldovan Code doesn't contain a precise definition of prostitution (what it represents and which actions/inactions are considered illegal). Considering that the Moldovan justice system is very sensitive to corruption, judges "play" with terms, allowing different types of fines and penalties that are more or less stringent, making Moldova a true "paradise" for procurers marginalized by laws currently in effect in member States of the EU. Another major problem is the existence of proven complicity of some authorities, which has been reflected in suspended or acquitted criminal cases for no ostensible reason. More and more testimonies of people in prostitution highlight the existence of "collaboration" between themselves and the local police. This has given rise to a new phenomenon, making the fight against prostitution even more difficult. These corrupt prosecutors are the image of a society devastated by the developments of recent decades, constantly in search of an identity and possessing fairly limited means to face social and economic ills (Unimedia, July $22^{\text {nd }}, 2014$ ).

Most of the recommendations refer to the reform of criminal procedures and the protection of 
victims and witnesses who are called upon to deal directly with procurers during investigations. Foreign actors have asked the Republic of Moldova to further its efforts in the fight against corruption in the judicial system.

\section{References}

1) «Cazul fetelor care făceau videochat în bibliotecă! Trebuie identificate persoanele ce recrutează tinere », Realitatea, January $7^{\text {th }}$, 2015.

2) «Decision of the Plenum of th Supreme Court of Justice of the Republic of Moldova on application of legislative previsions in cases of trafficking in human beings and trafficking in children - no.37 of 22 November $2004 »$, Bulletin of the Supreme Court of Justice of the Republic of Moldova, no.8, 2005.

3) «Investigație. Mărturisirile unor prostituate din Republica Moldova », Unimedia, vidéo, July $22^{\text {nd }}, 2014$.

4) « Legea privind castrarea chimică a pedofililor este neconstituţională », TRM Moldova, July $8^{\text {th }}, 2013$.

5) «Masaj erotic cu BONUS: Cat plateau clientii pentru prostitutie. Afacerea, descoperita de oamenii legii », ProTV Moldova, July $8^{\text {th }}$, 2015 .

6) «O femeie pentru 60 de minute », Ziarul de Garda, February $7^{\text {th }}, 2013$.

7) «Patru fete din Moldova au facut videochat erotic in bibliotecile din Chisinau. Ce PEDEAPSA incredibila au primit », Stirile Protv Romania, January $7^{\text {th }}, 2015$.

8) «Procuratura: o femeie învinuită de proxenetism riscă 'ani grei de închisoare' », MoldovaNews, May $8^{\text {th }}, 2015$.

9) «Servicii sexuale şi masaj erotic la domiciliu. Deservea câte patru clienţi pe zi VIDEO », Publika, October $4^{\text {th }}, 2012$.

10) «Traficul de ființe umane s-a diminuat în urma regimului liberalizat de vize cu UE », Moldpres, May $11^{\text {th }}, 2015$.

11) Council of Europe, Report submitted by the Moldovan authorities on measures taken to comply with Committee of the Parties Recommendation CP(2012)6 on the implementation of the Council of Europe Convention on Action against Trafficking in Human Beings, Committee of the Parties to the Council of Europe Convention on Action against Trafficking in Human Beings, CP(2014)8, June $12^{\text {th }}, 2014$.

12) Codul Contravenţional al Republicii Moldova, Parlamentul, Republica Moldova, COD nr.218 din 24.10.2008, CCRMM218/2008, January $16^{\text {th }}, 2009$, http://lex.justice.md/md/330333/

13) Covrig R., «Director de televiziune, reținut. Acuzaţii de trafic de carne vie și proxenetism », DCNews, December $19^{\text {th }}, 2014$.

14) CRIDES/Fondation Scelles, Revue de l'actualité internationale de la prostitution, 2013.

15) CRIDES/Fondation Scelles, Revue de l'actualité internationale de la prostitution, 2014.

16) GRETA (Group of Experts on Action against Trafficking in Human Beings), Council of Europe, Reply from the Republic of Moldova to the Questionnaire for the evaluation of the implementation of the Council of Europe Convention on Action against Trafficking in Human Beings by the Parties, Second evaluation round (Reply submitted on 11 February 2015), GRETA(2015)4, Strasbourg, March $4^{\text {th }}, 2015$.

17) Hotline Service - a decade of activity: Aspects of migration and trafficking in human beings in the Republic of Moldova, International Center for Women Rights Protection and Promotion La Strada Moldova, Chisinau, 2012.

18) Munteanu G., «Video-chat erotic și PORNOGRAFIC, în capitală. 'Munceau' 19 fete », Ziarul National, April 30 ${ }^{\text {th }}, 2015$.

19) National Report on preventing and combating trafficking in human beings 2014, National Committee for Combating Trafficking in Human Beings, Permanent Secretariat, Chisinau, 2015. 
20) Organized Crime and Corruption Reporting Project (OCCRP), «Interviews from the inside - Viorica Ursu, Human Trafficking, 10 years Sentence », Jail Crunch, Video, 2014, https://www.reportingproject.net/jailcrunch/vi deo.php?id=0

21) Petrov S., « Modeling sau prostituție de lux? », Promotime, January $3^{\text {rd }}, 2015$.

22) Raport de monitorizare a procesului de implementare a Strategiei Sistemului naţional de referire pentru protecţia şi asistenţa victimelor şi potenţialelor victime ale traficului de fiinţe umane pe perioada anului 2014, Ministerul Muncii, Protectiei Sociale si Familie, Chisinau, April 22 ${ }^{\text {nd }}, 2015$.

23) Sesiunea a IV-a ORDINAR $\breve{A}$ - IUNIE 2012 (session du Parlement), Dezbateri Parlamentare, Parlamentul Republicii Moldova de legislatura a XIX-a, June $5^{\text {th }}, 2012$.

24) Training on Human-Rights Approach to combating human trafficking for the 20142016 National Action Plan (NAP), National Committee for Combating Trafficking in Human Beings, Permanent Secretariat, November 2013.

25) U.S. Department of State, Trafficking in Persons Report, June 2014.

26) U.S. Department of State, Trafficking in Persons Report, July 2015.
27) Vizdoga I., Roman D., Donciu A. et al., Analytical study on the investigation and trial of cases of trafficking in persons and related offences, International Organization for Migration (IOM), Chisinau, 2013.

28) Office of the Prosecutor General of the Republic of Moldova: http://procuratura.md/md/newslst/1211/1/6284 I

29) http://www.gbv.de/dms/subhamburg/385865996.pdf

30) http://www.un.org/womenwatch/daw/egm/eqlmen/docs/EP.6_Mindicanu.pdf

31) http://www.wunrn.org/news/2006/06 $05 \quad 06 / 0$ 61206 moldova report.pdf

32) https://gramaticamea.wordpress.com/furtherreading-analyzing-and-discussing/ 